\title{
Inhibition Effects of Cobalt Nano Particles Against Fresh Water Algal Blooms Caused by Microcystis and Oscillatoria
}

\author{
Anusha L. ${ }^{1}$, Chingangbam Sushmita Devi ${ }^{2}$, Sibi G. ${ }^{3,}$ * \\ ${ }^{1}$ Department of Biotechnology, Bangalore City College, Bengaluru, India \\ ${ }^{2}$ Department of Microbiology, Bangalore City College, Bengaluru, India \\ ${ }^{3}$ Department of Biotechnology, Indian Academy Degree College-Autonomous, Bengaluru, India
}

Email address:

gsibii@gmail.com (Sibi G.)

${ }^{*}$ Corresponding author

\section{To cite this article:}

Anusha L., Chingangbam Sushmita Devi, Sibi G. Inhibition Effects of Cobalt Nano Particles Against Fresh Water Algal Blooms Caused by Microcystis and Oscillatoria. American Journal of Applied Scientific Research. Vol. 3, No. 4, 2017, pp. 26-32.

doi: 10.11648/j.ajasr.20170304.12

Received: June 17, 2017; Accepted: June 28, 2017; Published: November 28, 2017

\begin{abstract}
Cyanobacterial blooms deplete nutrients, reduce water clarity, exhaust carbon di oxide and produces secondary metabolites which negatively affect aquatic organisms and water quality. Control of algal blooms using metal nano particles is one effective method for the safety of water environment. Cobalt nano particles (CoNPs) were synthesized and tested against microalgae isolated from fresh water cyanobacterial blooms by assessing the effects on growth rate, biomass concentration, photosynthetic pigments concentration and antioxidant enzyme activity. Microcystis and Oscillatoria were identified as the predominant isolates from algal blooms and treated with varying concentrations $\left(1,2,3,4\right.$ and $\left.5 \mathrm{mg} \cdot \mathrm{L}^{-1}\right)$ of CoNPs. Steady decline in the growth rate of microalgae was observed at the end of 5 days indicating the toxicity of CoNPs on microalgal growth. At the end of cultivation period, $78 \%$ and $88 \%$ of reduction in biomass concentration of Microcystis and Oscillatoria were observed at $5 \mathrm{mg} \cdot \mathrm{L}^{-1}$ of CoNPs. The chlorophyll content was reduced from 1.53 to $0.24 \mathrm{mg} \cdot \mathrm{L}^{-1}$ in Microcystis and 1.63 to $0.29 \mathrm{mg} \cdot \mathrm{L}^{-1}$ in Oscillatoria. There was a $69.3 \%$ and $73.2 \%$ decrease in carotenoid content of Microcystis and Oscillatoria respectively. Both protein and carbohydrate contents of the microalgae were reduced with increasing concentration of nano particles. The decrease in Super oxide dismutase (SOD) activity with increased nanoparticle concentration reveals the formation of stress in the microalgae. The increasing GSH activity proved the effect of CoNPs on the activation of antioxidative enzymes to protect the cells. This study demonstrates the efficiency of cobalt nano particles (CoNPs) on inhibition of fresh water algal blooms thereby reducing the eutrophication problem.
\end{abstract}

Keywords: Microalgae, Nano Particles, Algal Bloom, Microcystis, Oscillatoria

\section{Introduction}

Microalgae utilize light, carbon di oxide and nutrients to produce biomass in water bodies which is consumed by planktonic herbivores. The rate of biomass production depends on irradiance and nutrient availability and if consumption does not keep pace with biomass productivity, excess growth occurs. Algal biomass accumulations lead to visible discoloration of the water and referred as blooms [13]. Blooms due to rapid growth, division rates, stable water column and higher nutrient upload leads to adverse tastes, odours and toxicity of affected water bodies [4]. Higher cell densities of blooms rapidly deplete nutrients, increase turbidity, and exhaust $\mathrm{CO}_{2}$ thus causing decline in biomass leading to decaying, odoriferous, unsightly scums. These scums contain variety of microorganisms which produce significant chemical and biological changes, release of toxic compounds, accelerated release of nutrients from sediments that aggravates eutrophication and blooms $[5,6]$.

Chlorophytes, dinoflagellates, diatoms and cyanobacteria are the major freshwater algal phyla that produce blooms [7, 8]. Among these, Cyanobacterial blooms may cause social, 
economic and environmental problems [9-11]. Secondary metabolites produced by cyanobacteria are elated to toxic effects on aquatic flora and fauna [12]. Microcystis and Oscillatoria are traditionally confined to nutrient enriched impoundments due to their unique adaptability to nutrient conditions. Bloom controlling strategies include mechanical, biological, chemical, genetic and environmental control. However, effective methods for preventing algal blooms are important for the safety of water environment.

Recently, metal nanoparticles are showing imperative role in the biological and environmental aspects [13]. Nanoparticles between 1 and $100 \mathrm{~nm}$ have been reported as toxic to algae [14-16]. Inhibitory effects of metal oxide nanoparticles against microalgae due to reactive oxygen species generation [17, 18], mechanical damage [19], light shading effect [20], interactions with nutrients [21] and other factors [22] were reported. Accordingly, the aim of this study was to determine the inhibitory effect of cobalt nano particles (CoNPs) on microalgae isolated from fresh water cyanobacterial blooms by assessing the effects on growth rate, biomass concentration, photosynthetic pigments concentration and antioxidant enzyme activity.

\section{Materials and Methods}

\subsection{Collection and Identification of Microalgae}

Algal blooms were collected from fresh water lakes and the samples were stored in a refrigerator until use and formalin (1/10) was used for preservation. 2-3 drops of algae rich water was transferred into the glass slide along with small bits of filaments, tufts and mats. The samples were teased as much as possible, covered with cover slip and observed under normal compound microscope. Identification of the algal samples following standard protocols described earlier [23, 24] revealed that Microcystis and Oscillatoria were the major isolates from the algal blooms.

\subsection{Isolation and Sub Culturing}

The serial transfer of single algal cultures into new medium was performed in a laminar air flow hood. An aliquot of the culture suspension was inoculated into fresh medium using a Pasteur pipette and $1 \mathrm{~mL}$ bulb. Cultures (2-4 $\times 10^{4}$ cells $/ \mathrm{ml}$ ) were maintained in a single room having approximately 500 square feet of floor space. The temperature of the room was kept at $20 \pm 1{ }^{\circ} \mathrm{C}$ using an air conditioner. The relative humidity was kept at $31 \pm 1 \%$, the flasks were shaken by hand and randomly placed in a growth cabinet $\left(27 \pm 1^{\circ} \mathrm{C}, 12: 12 \mathrm{~h}\right.$ light/dark cycle, Philips TL $40 \mathrm{~W}$ cool white fluorescent lighting, $140 \mu \mathrm{mol}$ photons $/ \mathrm{m}^{2} / \mathrm{s}$ ) for 15-20 days. Aeration was done for 8 hours daily using aquarium motor. Cultivation was done simultaneously in open systems by exposing the culture bottles to natural sunlight with aeration.

\subsection{Synthesis of Cobalt Nano Particles (CoNPs)}

Cobalt nano particles were prepared using Cobalt chloride $\left(\mathrm{CoCl}_{2} \cdot 6 \mathrm{H}_{2} \mathrm{O}\right)$ and hydrazine monohydrate as raw materials. A $20 \mathrm{ml}$ solution of $10 \% \mathrm{CoCl}_{2} \cdot 6 \mathrm{H}_{2} \mathrm{O}$ was added with $100 \mathrm{ml}$ of sodium succinate $(7.2 \mathrm{~g})$ and heated at $70^{\circ} \mathrm{C}$ for 10 minutes. This was followed by addition of $10 \mathrm{ml}$ of Polyvinyl alcohol $(0.1 \mathrm{~g})$ and drop wise addition of $30 \%$ hydrazine hydrate with constant stirring. The solution was filtered through Whatman filter paper, washed several times with deionized water and dried over night at $120^{\circ} \mathrm{C}$ temperature. The dried powder is analyzed by UV-Vis spectrophotometer.

\subsection{Inhibition Assay}

Cobalt nano particles (CoNPs) prepared as above was tested to determine the inhibitory effect on Microcystis and Oscillatoria. BG11 medium was used to cultivate the microalgae and batch cultures of isolated microalgae were grown in different concentrations $\left(1 \mathrm{mg} \cdot \mathrm{L}^{-1}, 2 \mathrm{mg} \cdot \mathrm{L}^{-1}, 3 \mathrm{mg} \cdot \mathrm{L}^{-1}\right.$, $4 \mathrm{mg} \cdot \mathrm{L}^{-1}$ and $5 \mathrm{mg} \cdot \mathrm{L}^{-1}$ ) of metal nano particles for a period of 5 days.

\subsection{Growth Rate and Biomass Concentration}

Specific growth rate $(\mu)$ of the microalgae was calculated according to the following formula.

$$
\mu=\frac{\ln \left(\mathrm{N}_{\mathrm{t}} / \mathrm{N}_{0}\right)}{\mathrm{T}_{\mathrm{t}}-\mathrm{T}_{0}}
$$

Where, $\mathrm{N}_{\mathrm{t}}$ and $\mathrm{N}_{0}$ are the dry cell weight concentration $\left(g \cdot L^{-1}\right)$ at the end $\left(T_{t}\right)$ and start $\left(T_{0}\right)$ of log phase respectively.

Biomass $\left(\mathrm{g} \cdot \mathrm{L}^{-1}\right)$ of microalgae grown in the presence of metal nanoparticles was determined by measuring the optical density of samples at $600 \mathrm{~nm}\left(\mathrm{OD}_{600}\right)$ using UVVis spectrophotometer. Biomass concentration was then calculated by multiplying $\mathrm{OD}_{600}$ values with 0.6 , a predetermined conversion factor obtained by plotting $\mathrm{OD}_{600}$ versus dry cell weight (DCW). DCW was determined gravimetrically by centrifuging the algal cells $(3,000 \times \mathrm{g}, 10 \mathrm{~min})$ and drying.

$$
\text { Biomass concentration }=\mathrm{OD}_{600} \times 0.6
$$

\subsection{Chlorophyll and Carotenoids Estimation}

Chlorophyll contents of the microalga were estimated according to Becker [25] (1994). Algal cells were centrifuged and extracted with acetone overnight. The extract was centrifuged at $3000 \mathrm{x} \mathrm{g}$ for $5 \mathrm{mins}$ and the chlorophyll content in the supernatant were determined by measuring the optical densities at 645 and $663 \mathrm{~nm}$ in a spectrophotometer and then calculated using the following equation.

$$
\mathrm{Chl}(\mathrm{mg} / \mathrm{l})=8.02 \times \mathrm{OD}_{663}+20.21 \times \mathrm{OD}_{645}
$$

Carotenoids were determined by following the procedure of Whyte [26]. Algal cells were centrifuged and treated with centrifuging the algal cells and treated with $\mathrm{KOH}$ $(60 \% \mathrm{w} / \mathrm{w})$. The mixture was homogenized and warmed to $40^{\circ} \mathrm{C}$ for 40 mins and extracted using ethyl ether. The 
solvent was evaporated followed by resuspending in acetone and the optical density was measured at $444 \mathrm{~nm}$. Total carotenoids were calculated using the below equation.

$$
\mathrm{Ct}(\mathrm{mg} / \mathrm{L})=4.32 \times \mathrm{OD}_{444}-0.0439
$$

\subsection{Protein and Carbohydrate Assay}

The extraction of proteins from microalgae was performed using alkali method. Aliquots of algal sample were centrifuged and $0.5 \mathrm{~N} \mathrm{NaOH}$ was added to the pellet followed by extraction at $80^{\circ} \mathrm{C}$ for 10 mins. The mixture was centrifuged and protein content of the supernatant was estimated using Bovine Serum Albumin (BSA) as standard [27].

Cellular carbohydrates were estimated using the anthrone method described by Gerhardt et al., [28] after hot alkaline extraction [29]. Briefly, microalgal pellets were resuspended in distilled water and then heated in $40 \%(\mathrm{w} / \mathrm{v}) \mathrm{KOH}$ at $90^{\circ} \mathrm{C}$ for $1 \mathrm{~h}$. After cooling down, ice cold ethanol was added and stored at $-20^{\circ} \mathrm{C}$ overnight followed by centrifugation. The pellet was resuspended in distilled water and then reacted with anthrone reagent. D-glucose was used as standard and the colour development was read at $578 \mathrm{~nm}$ in a spectrophotometer.

\subsection{Superoxide Dismutase Assay}

Superoxide dismutase (SOD) assay was carried out by subsequently pipetting the following solutions into the cuvette; $0.8 \mathrm{ml}$ of Triethanolamine diethanolamine (100 $\mathrm{mM}), 40 \mu \mathrm{l}$ NADPH $(7.5 \mathrm{mM}), 25 \mu \mathrm{l}$ EDTA- $\mathrm{MnCl}_{2}(100$ $\mathrm{mM} / 50 \mathrm{mM}$ ) and $0.1 \mathrm{ml}$ of microalgal sample. The contents were mixed thoroughly and the absorbance was read at 340 $\mathrm{nm}$ over a $5 \mathrm{~min}$ period. Then added $0.1 \mathrm{ml}$ of mercaptoethanol $(10 \mathrm{mM})$ and the contents were mixed. The decrease in absorbance for about $20 \mathrm{~min}$ was measured to allow full expression of the chain leading to NADPH oxidation [30].

\subsection{GSH Assay}

The algal cells were pelleted by centrifuging at $8000 \mathrm{rpm}$ for 10 mins and added with $2.5 \mathrm{ml}$ of $\mathrm{Na}_{2} \mathrm{PO}_{4}(0.3 \mathrm{M})$. A 0.25 $\mathrm{ml}$ of -5 '-dithiobis [2-nitrobenzoic acid] (DTNB) reagent was added and the mixture was incubated at $37^{\circ} \mathrm{C}$ for 10 mins. After incubation, the absorbance was read at $412 \mathrm{~nm}$ in a $\mathrm{UV}-\mathrm{Vis}$ spectrophotometer and the concentration of GSH was determined using the standard curve [31].

\section{Results and Discussion}

Microcystis and Oscillatoria were found as predominant microalgal species in this study (Figure-1a and 1b). The change in the colour of cobalt chloride solution indicated the synthesis of nano particles which were further characterized by UV-Vis spectroscopy. Nano sized cobalt exhibits a strong absorption due to collective oscillation of conduction of electrons under suitable radiation and this phenomenon is known as Plasmon resonance. The Plasmon band of CoNPs was observed at $400-500 \mathrm{~nm}$ and the maximum absorption was found at $440 \mathrm{~nm}$ which confirmed the nano sized particles. The isolates were purified and cultivated in the presence of cobalt nano particles using BG 11 medium for a period of 5 days.

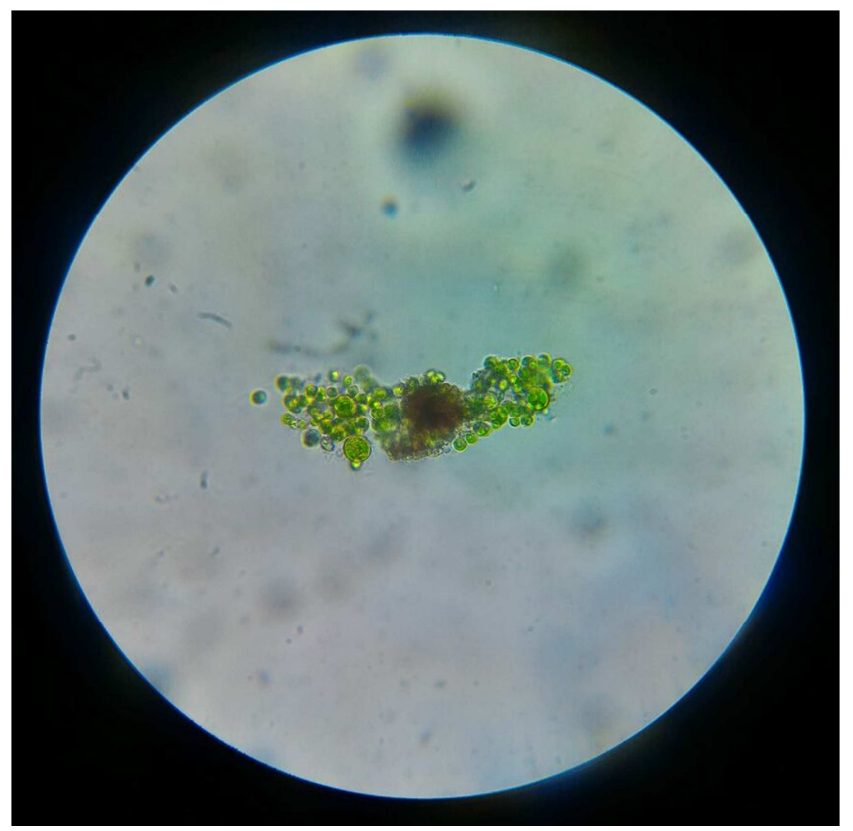

Figure 1a. Microcystis species.

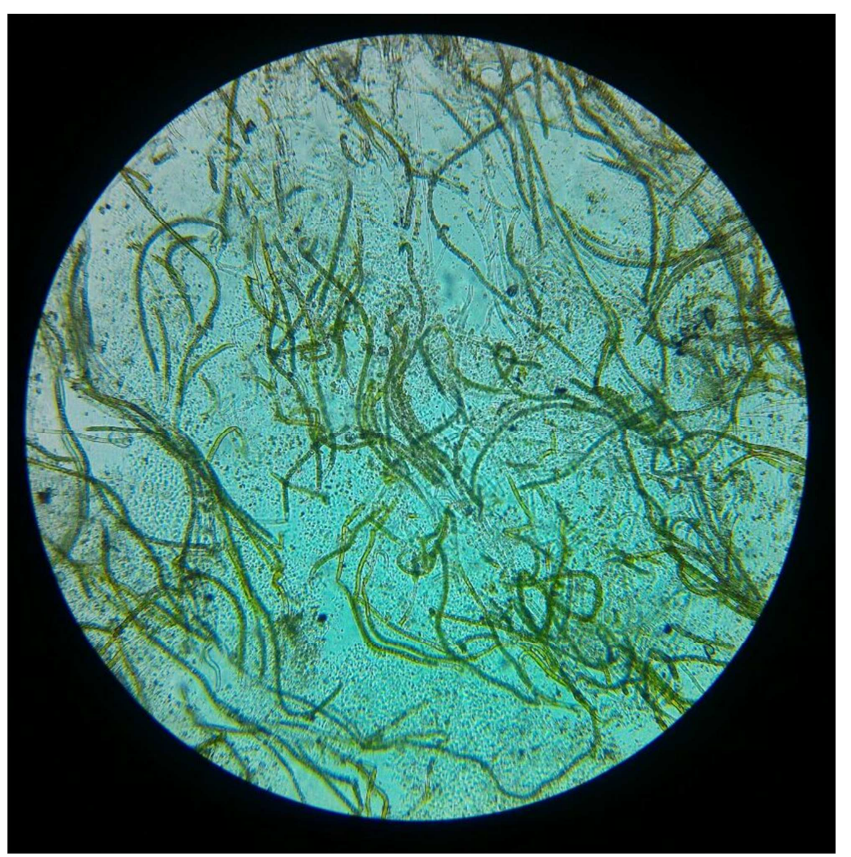

Figure 1b. Oscillatoria species.

In order to evaluate the effect of cobalt nanoparticle on growth of Microcystis and Oscillatoria strains, $3 \mathrm{ml}$ of microalgal suspension with exponential growth phase was harvested from stock cultures and was added to $150 \mathrm{ml}$ of BG11 medium. Microalgal cells were exposed to increasing nominal concentration of cobalt nano particles 
including a control $\left(1,2,3,4\right.$ and $\left.5 \mathrm{mg} \cdot \mathrm{L}^{-1}\right)$. Growth medium without nano particles was served as control and the experiments were performed in triplicates. Specific growth rate is the measurement of microalgal growth and the presence of metal nanoparticle reduced the overall growth rate in both Microcystis and Oscillatoria. Steady decline in the growth rate of microalgae was observed at the end of 5 days (Figure-2 and 3) indicating the toxicity of CoNP on microalgal growth. In eutrophic water, Microcystis is reported as one of the most worldwide toxic bloom forming cyanobacteria [32]. Toxins produced by Microcystis affect both aquatic animals and humans [33]. Effect of metal nanoparticles on growth inhibition of Microcystis was reported earlier [34-36, 9]. Wang et al. [35] reported that $0.5 \mathrm{mg} \cdot \mathrm{L}^{-1}$ concentration of copper oxide nano particles produced toxicity on Microcystis aeruginosa where as Park et al. [34] described that 1 $\mathrm{mg} \cdot \mathrm{L}^{-1}$ had significantly inhibited the algal growth. In this study CoNPs at a concentration of $1 \mathrm{mg} \cdot \mathrm{L}^{-1}$ was found inhibiting algal growth over a period of time.

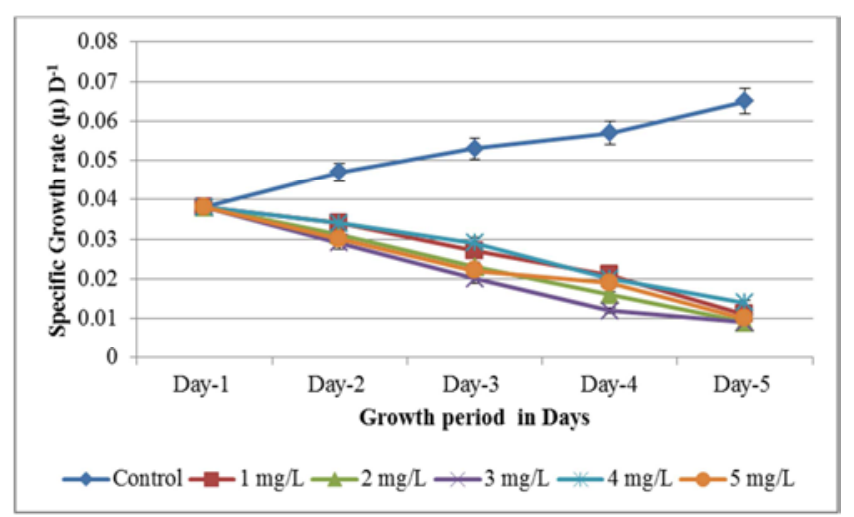

Figure 2. Specific growth rate of Microcystis at various concentrations of CoNPS.

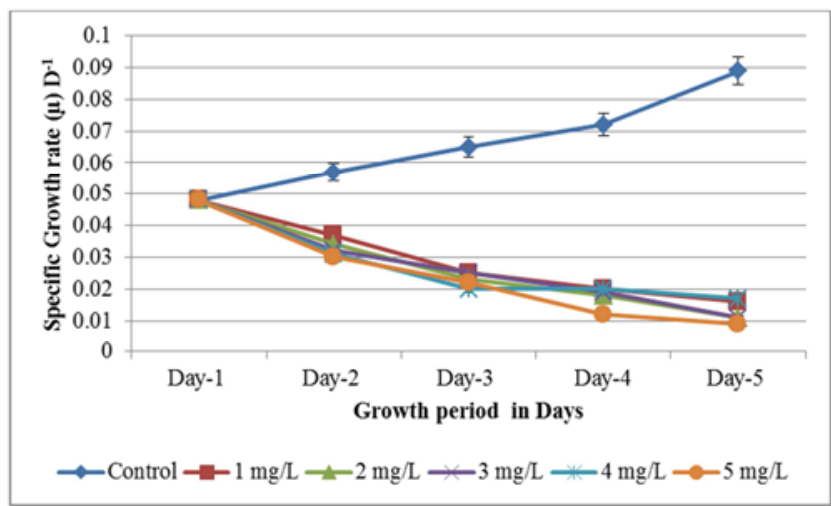

Figure 3. Specific growth rate of Oscillatoria at various concentrations of CoNPs.

The effect of CoNPs on biomass of Microcystis and Oscillatoria are represented in Figure-4 and 5. The experiments were performed for a period of 5 days with an initial biomass concentration of $0.065 \mathrm{mg} \cdot \mathrm{L}^{-1}$. CoNPs had significant effect on biomass content of the tested microalgae and at the end of cultivation period $0.014 \mathrm{mg} \cdot \mathrm{L}^{-1}$ was observed in Microcystis which was $78 \%$ lesser than that of initial concentration. Similarly, increased CoNPs concentration reduced the biomass content of Oscillatoria which was $88 \%$ lower than initial concentration.

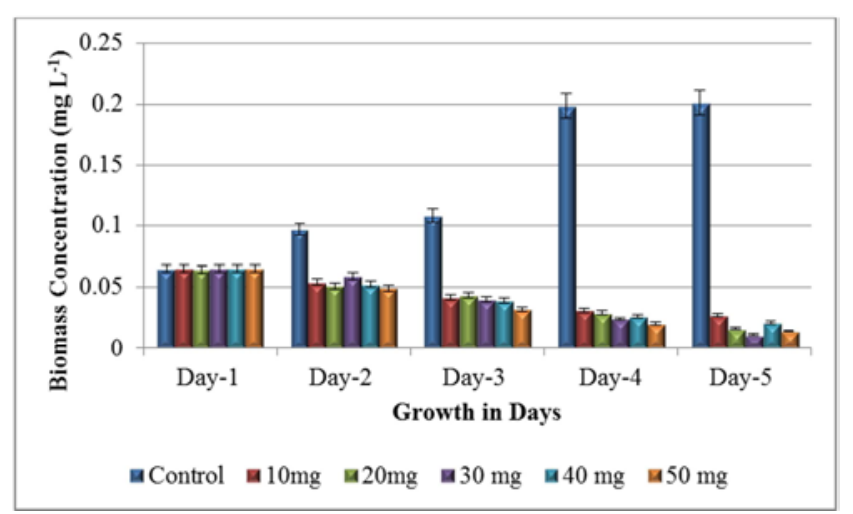

Figure 4. Biomass concentration of Microcystis at various concentrations of CoNPs.

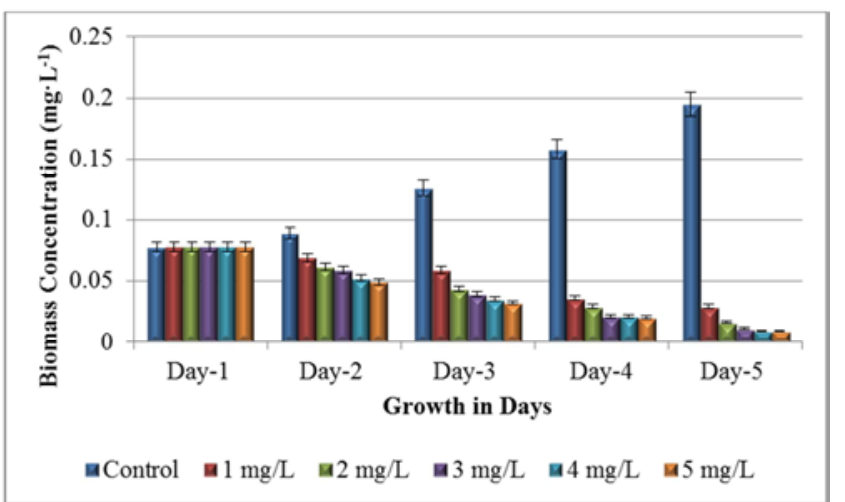

Figure 5. Biomass concentration of Oscillatoria at various concentrations of CoNPs.

Most reports demonstrated that increasing metal concentrations resulted in greater stress effect and reduction of algal growth rate was due to decrease in algal photosynthesis. This was supported in the present study where chlorophyll content was decreased with increasing nano particles concentration. The pigment concentration was reduced from 1.53 to $0.24 \mathrm{mg} \cdot \mathrm{L}^{-1}$ in Microcystis and 1.63 to $0.29 \mathrm{mg} \cdot \mathrm{L}^{-1}$ in Oscillatoria (Figure-6). The mechanism of toxicity of heavy metals to cyanophyta are not fully known but several heavy metals retard the flow of electrons in electron transfer reaction in mitochondria and chloroplast and thus can be expected to have a detrimental effect on respiration, photosynthesis and other processes related to it. The other mechanism proposed for the inhibition is the replacement of magnesium in the chlorophyll molecule, consequently cells accumulate protoporphyrin and synthesis of chlorophyll is blocked, this may be attributed to inhibition of reduction step in the biosynthetic pathways of this pigment. The results were similar for carotenoid contents where there was a $69.3 \%$ and $73.2 \%$ decrease in Microcystis and Oscillatoria respectively (Figure-7). 


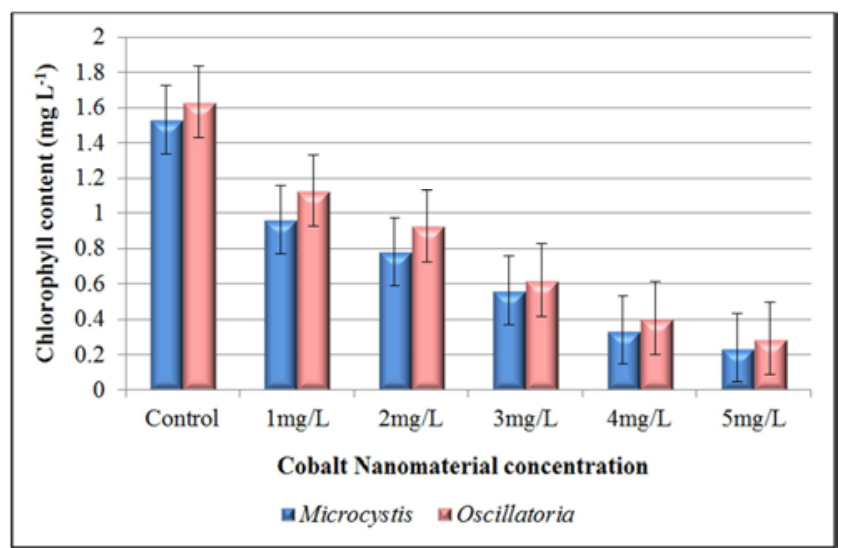

Figure 6. Chlorophyll content of algal bloom at various concentrations of CoNPs.

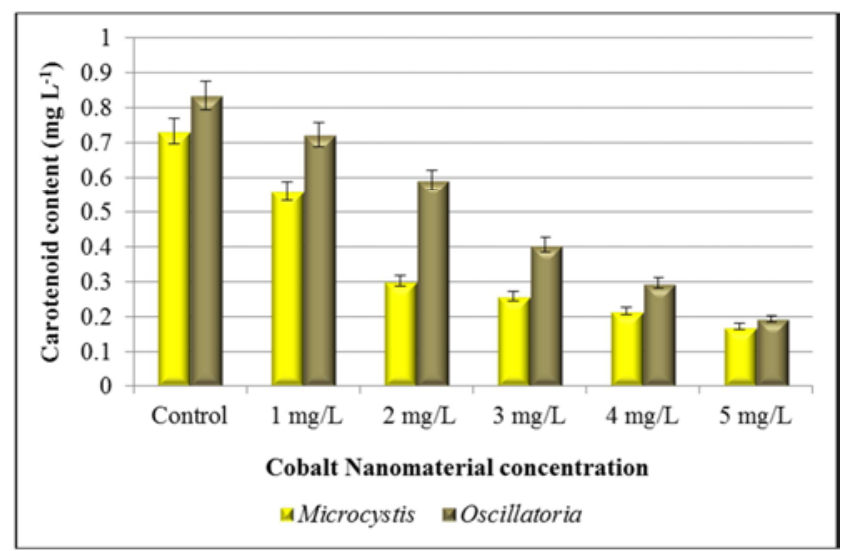

Figure 7. Carotenoid content of algal bloom at various concentrations of CoNPs.

Damage of cell membrane at high metal concentrations will lead to uncontrolled release/intake of electrolytes which may be responsible for the inhibition of growth. This might be linked with the synthesis of carbohydrates and proteins. This was confirmed by the data of proteins, where the trend in the accumulation of protein went parallel in most cases with the data of the photosynthetic pigments (Figure-8 and 9). This means that the efficiency of photosynthetic apparatus and the production of proteins and carbohydrates were closely associated and conclude that toxicity of metal nanoparticles disturbed both components.

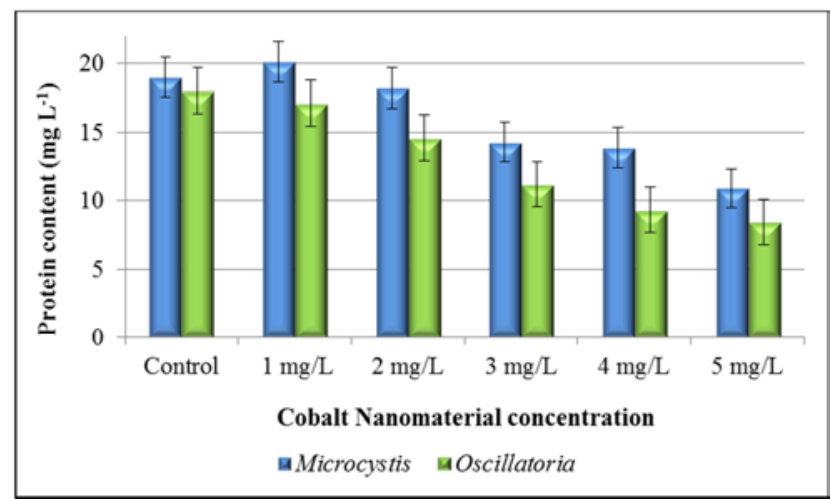

Figure 8. Protein content of algal bloom at various concentrations of CoNPs.

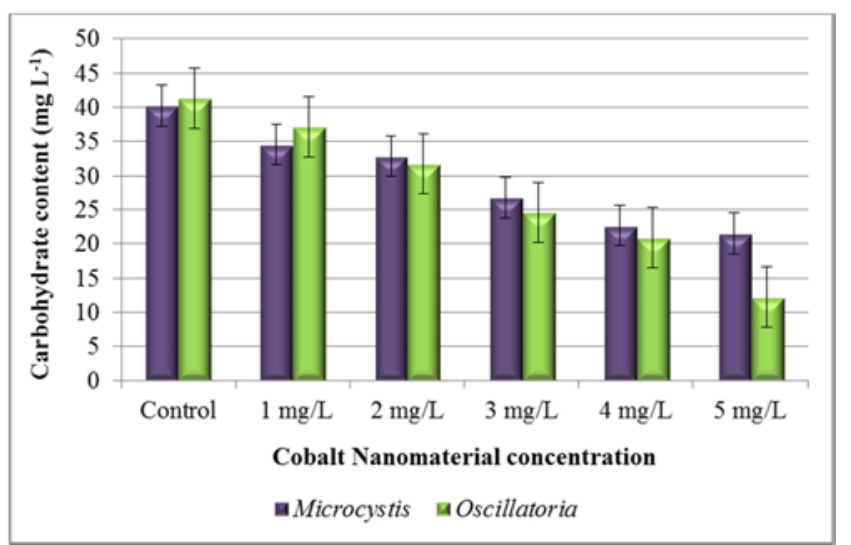

Figure 9. Carbohydrate content of algal bloom at various concentrations of CoNPs.

Metals also cause oxidative damage [37] and algal tolerance for metals partly depends on its defense responses to prevent oxidative damage [38]. Algae contain several enzymatic and nonenzymatic antioxidant defense systems to maintain the concentration of reactive oxygen species to protect cells from damage [39]. The primary scavenging enzymatic antioxidant defense system includes superoxide dismutase, calalase, glutathione reductase and ascorbate peroxidise [40]. In this study, the change in the antioxidant defense system was measured with SOD and GSH as biomarkers. SOD is an enzymatic antioxidant that can scavenge reactive oxygen species (ROS) generated by heavy metal stress. The change in SOD activity during the experiments is shown in Figure 10.

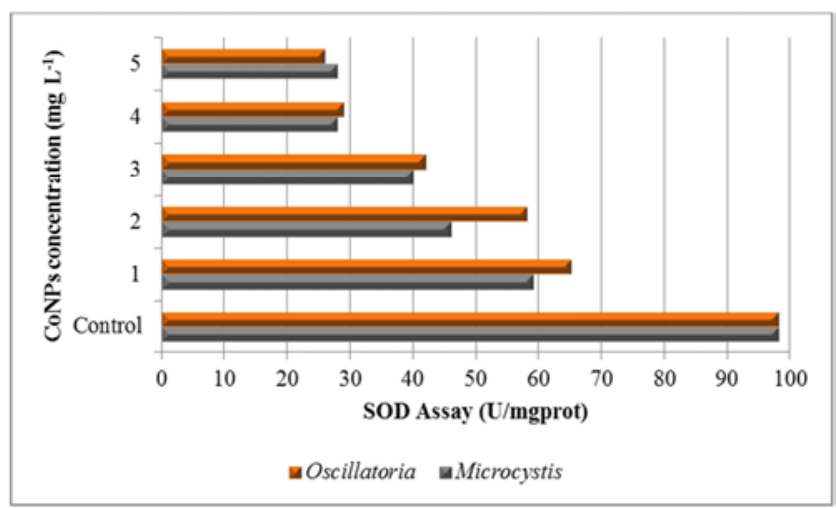

Figure 10. SOD Assay.

GSH is another major free radical remover and protect proteins from the oxidation of protein thiol groups [41]. Algae can respond to heavy metal stress by increasing the GSH concentration. The influence of GSH concentration by CoNPs is shown in Figure-11. As nanoparticles have a large surface area-to volume ratio, it is reported that NPs react strongly with cell compartments which increase free radical production and causing oxidative stress. 


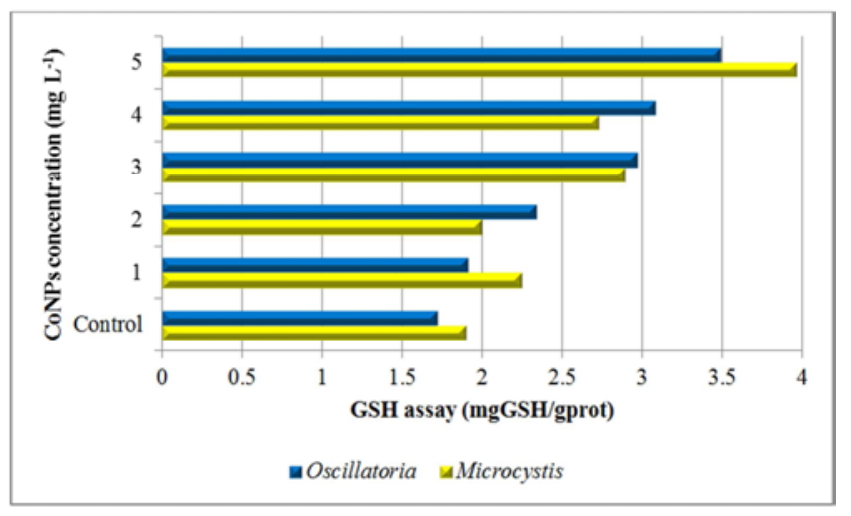

Figure 11. GSH Assay.

\section{Conclusion}

In conclusion, the inhibitory effect of CoNPs become greater with an increase in concentrations and suggested that the reduction in the growth rate of algae due to a decrease in algal photosynthesis caused by the inhibition of photosynthetic pigments and cellular components. The decrease in SOD activity with increased nanoparticle concentration reveals the formation of stress in the microalgae. The increasing GSH activity proved the effect of CoNPs on the activation of antioxidative enzymes to protect the cells. This study demonstrates the efficiency of cobalt nanoparticles (CoNPs) on inhibition of fresh water algal blooms thereby reducing the eutrophication problem.

\section{References}

[1] Fogg GE. (1969). The physiology of an algal nuisance. Proc. R. Sco. London. Ser. B. 173: 175-189.

[2] Reynolds CS., Walsby AE. (1975). Water blooms. Biol. Rev. 50: 437-481.

[3] Vallentyne JR. (1974). The Algal Bowl. Lakes and Man. Department of the Environment, Fisheries and Marine Service, Ottawa, Canada. 185 p.

[4] Chorus I., Bartram J. (1999). Toxic cyanobacteria in water. E\&FN Spon, London. 416 p.

[5] Lund JWG. (1965). The ecology of freshwater phytoplankton. Biol. Rev. Cambridge Philos. Soc. 40: 231-293.

[6] Paerl HW. (1988). Nuisance phytoplankton blooms in coastal, estuarine and inland waters. Limnol. Oceanogr. 33: 823-847.

[7] Round FE. (1965). The Biology of the Algae. Arnold Press. London.

[8] Sournia A. (1978). Phytoplankton manual. UNESCO, Paris.

[9] Duong TT, Le TS, Tran TTH, Nguyen TK, Ho CT, Dao TH et al., (2016). Inhibition effect of engineered silver nanoparticles to bloom forming cyanobacteria. Adv. Nat. Sci.: Nanosci. Nanotechnol. 7: 035018.

[10] Hu LB, Zhou W, Yang JD, Chen J, Yin YF, Shi ZQ. (2011) Cinnamaldehyde induces PCD-like death of via reactive oxygen species. Water Air Soil Pollut. 217(1):105-113.
[11] Angeline K, Prepas EE, Spink D, Hrudey SE. (1994). Chemical control of hepatotoxic phytoplankton blooms: implication for human health. Water Research, 29: 1845.

[12] Wiegand, C., Pflugmacher, S. (2005). Ecotoxicological effects of selected cyanobacterial secondary metabolites a short review. Toxicol. Appl. Pharmacol. 203: 201-218.

[13] Burda C, Chen X, Narayanan R, El-Sayed MA. (2005). Chemistry and properties of nanocrystals of different shapes. Chem Rev 105(4): 1025-1102.

[14] Burchardt AD, Carvalho RN, Valente A, Nativo P, Gilliland D, Garcia CP, Passarella R, Pedroni, Rossi F, Lettieri T. (2012). Effects of Silver Nanoparticles in Diatom Thalassiosira pseudonana and Cyanobacterium Synechococcus sp. Environ. Sci. Technol., 46(20): 1133611344.

[15] Oukarroum A, Bras S, Perreault F and Popovic R. (2012). Inhibitory effects of silver nanoparticles in two green algae, Chlorella vulgaris and Dunaliella tertiolecta. 78: 80-85.

[16] Saison C, Perreault F, Daigle JC, Fortin C, Claverie J, Morin M, Popovic R. (2010) Effect of core-shell copper oxide nanoparticles on cell culture morphology and photosynthesis (photosystem II energy distribution) in the green alga. Chlamydomonas reinhardtii. Aquat Toxicol 96(2):109-114.

[17] Xia B, Chen B, Sun X, Qu K, Ma F, Du M. (2015). Interaction of $\mathrm{TiO}_{2}$ nanoparticles with the marine microalga Nitzschia closterium: Growth inhibition, oxidative stress and internalization. Sci. Total Environ. 508: 525-533.

[18] Suman, T. Y, Rajasree, S. R. R, Kirubagaran, R. (2015). Evaluation of zinc oxide nanoparticles toxicity on marine algae Chlorella vulgaris through flow cytometric, cytotoxicity and oxidative stress analysis. Ecotoxicol. Environ. Saf. 113: 23-30.

[19] Castro-Bugallo, A, Gonzalez-Fernandez, A, Guisande, C, Barreiro, A. (2014). Comparative responses to metal oxide nanoparticles in marine phytoplankton. Arch. Environ. Contam. Toxicol. 67(4): 483-493.

[20] Sadiq, I. M, Pakrashi, S, Chandrasekaran, N, Mukherjee, A. (2011). Studies on toxicity of aluminium oxide $\left(\mathrm{Al}_{2} \mathrm{O}_{3}\right)$ nanoparticles to microalgae species: Scenedesmus sp. and Chlorella sp. J. Nanopart. Res. 13: 3287-3299.

[21] Manier, N, Bado-Nilles A, Delalain P, Aguerre-Chariol O, Pandard P. (2013). Ecotoxicity of non-aged and aged $\mathrm{CeO}_{2}$ nanomaterials towards freshwater microalgae. Environ. Pollut. 180: 63-70.

[22] Manzo, S, Miglietta M. L, Rametta G, Buono S, Francia, G. D. (2013). Toxic effects of $\mathrm{ZnO}$ nanoparticles towards marine algae Dunaliella tertiolecta. Sci. Total Environ. 445-446: 3716.

[23] Anderson, R. A. (2005). Algal Culturing Techniques. Elsevier Inc., Amsterdam.

[24] Stanier, R. Y., Kunisawa, R., Mandel, M. and Cohen-Bazire, G. (1971). Purification and properties of unicellular bluegreen algae (Order Chroococcales). Bacteriological Reviews, 35: 171-205.

[25] Becker EW. (1994). Microalgae: Biotechnology and Microbiology. Cambridge University Press, New York. 
[26] Whyte JC. (1987). Biochemical composition and energy content of six species of phytoplankton used in mariculture of bivalves. Aquaculture. 60:231-241.

[27] Lowry, O. H., Rosebrough, N. J., Farr, A. L. and Randall, RJ. (1951). Protein Measurement with the Folin Phenol Reagent. The Journal of Biological Chemistry, 193: 265-275.

[28] Gerhardt, P., Murray, R. G. E., Wood, W. A. and Krieg, N. R. (1994) Methods for General and Molecular Bacteriology. ASM, Washington DC.

[29] Leyva, A., Quintana, A., Sanchez, M., Rodriguez, E. N., Cremata, J. and Sanchez, J. C. (2008). Rapid and sensitive anthrone-sulfuric acid assay in microplate format to quantify carbohydrate in biopharmaceutical products: Method development and validation. Biologicals, 36: 134-141.

[30] Paoletti F, Mocali A. (1990). Determination of superoxide dismutase activity by purely chemical system based on NAD (P) H oxidation. Methods Enzymol. 186: 209-20.

[31] Anderson ME. (1985). Determination of glutathione and glutathione disulfide in biological samples. Methods Enzymol. 113:548-555.

[32] Humbert JF, Barbe V, Latifi A, Gugger M, Calteau A, Coursin T, Lajus A, Castelli V, Oztas S, Samson G, Longin C, Medigue C, de Marsac NT. (2013). A tribute to disorder in the genome of the bloom-forming freshwater cyanobacterium Microcystis aeruginosa. PLoS ONE 8: 70747.

[33] Yoshida M, Yoshida T, Kashima A, Takashima Y, Hosoda N, Nagasaki K, Hiroishi S (2008). Ecological dynamics of the toxic bloom-forming cyanobacterium Microcystis aeruginosa and its cyanophages in freshwater. Appl Environ Microbiol 74(10):3269-3273.
[34] Park H M, Kim KH, Lee HH, Kim JS and Hwang S J (2010). Selective inhibitory potential of silver nanoparticles on the harmful cyanobacterium Microcystis aeruginosa. Biotechnol Lett. 32: 423-428.

[35] Wang Z, Li J, Zhao J, Xing B. (2011). Toxicity and internalization of $\mathrm{CuO}$ nanoparticles to prokaryotic alga Microcystis aeruginosa as affected by dissolved organic matter. Environ Sci Technol 45(14):6032-6040.

[36] Sankar, R., Prasath, B. B., Nandakumar, R. et al. (2014). Growth inhibition of bloom forming cyanobacterium Microcystis aeruginosa by green route fabricated copper oxide nanoparticles. Environ Sci Pollut Res Int 21: 14232-14240.

[37] Zhang W, Xiong B, Chen L, Lin K, Cui X, Bi H, Guo M, Wang W. (2013). Toxicity assessment of Chlorella vulgaris and Chlorella protothecoides following exposure to $\mathrm{Pb}$ (II). Environ Toxicol Pharmacol. 36(1):51-57.

[38] Pinto E., Sigaud-kutner T., Leitao M. A., Okamoto O. K., Morse D., Colepicolo P. (2003). Heavy metal-induced oxidative stress in algae. J. Phycol. 39: 1008-1018.

[39] Abd El-Baky, H. H., El Baz, F. K. and El-Baroty, G. S. (2004). Production of antioxidant by the green alga Dunaliella salina. Int. J. Agri. Biol. 6: 49-57.

[40] Mittler, R., Vanderauwera, S., Gollery, M. and Van Breusegem, F. (2004). The reactive oxygen gene network of plants. Trends Plant Sci. 9: 490-498.

[41] Noctor, G., L. Gomez, H. Vanacker, and C. Foyer. (2002). Interactions between biosynthesis, compartmentation and transport in the control of glutathione homeostasis and signaling. J. Exp. Bot. 53: 1283-1304. 